\title{
OPTIMASI SINTESA ESTER MALTITOL ASAM LEMAK DARI MINYAK KELAPA SAWIT MENGGUNAKAN LIPASE GETAH PEPAYA SEBAGAI KATALISATOR
}

\section{(OPTIMIZATION OF THE ESTER MALTHITOL FATTY ACID SHYNTHESIS FROM PALM OIL USING PAPAYA LATEX LIPASE AS A CATALYSATOR)}

\author{
Ratri Retno Utami dan Alfrida Lullung \\ ${ }^{1}$ Balai Besar Industri Hasil Perkebunan (BBIHP) \\ `Email:ih_yutcu@yahoo.com
}

Naskah diterima tanggal 14 Januari 2013, disetujui tanggal 23 Mei 2013

\begin{abstract}
ABSTRAK
Penelitian optimasi sintesa Ester Maltitol Asam Lemak (EMALTAL) dari minyak kelapa sawit sebagai biosurfaktan telah dilakukan. Lipase getah pepaya digunakan sebagai katalisator dalam sintesa. Penelitian ini bertujuan untuk mempelajari optimasi sintesa biosurfaktan Ester Maltitol Asam Lemak (EMALTAL) dari minyak kelapa sawit dengan menggunakan lipase getah pepaya sebagai katalisator. Sebelum sintesa dilakukan, minyak kelapa sawit diubah menjadi Ester Metil Asam Lemak (EMAL). Kondisi optimal yang diperlukan untuk membentuk EMALTAL ditentukan dengan Response Surface Methode/RSM. Untuk mendapatkan konversi optimal sintesa EMALTAL, reaksi dipengaruhi oleh tiga variabel bebas yaitu waktu, kadar lipase getah pepaya dan suhu serta satu variabel terikat yang disebut respon yaitu konversi optimal sintesa EMALTAL. Dengan menggunakan metode respon permukaan (RSM), kondisi sintesis yang optimal diperoleh pada suhu $39,45{ }^{\circ} \mathrm{C}$, waktu 53,24 menit dan konsentrasi getah pepaya kasar 7,66 \% dengan hasil konversi surfaktan $28,68 \%$ dalam bentuk monoester. Karakterisasi dari EMALTAL menunjukkan titik leleh $24,5-27^{\circ} \mathrm{C}$, titik asap $180^{\circ} \mathrm{C}$ dan indeks refraksi 1,441 . EMALTAL yang dihasilkan merupakan monoester yang berfungsi sebagai emulsifier.
\end{abstract}

Kata kunci : biosurfaktan, minyak kelapa sawit, metode respon permukaan, ester maltitol asam lemak, lipase getah pepaya

\section{ABSTRACT}

Research optimization of the ester Maltitol Fatty Acid (EMALTAL) synthesis from palm as biosurfactant has been conducted. Papaya latex lipase used as a catalyst in the synthesis. This research aims to study the optimization of biosurfactant synthesis Maltitol Fatty Acid Esters (EMALTAL) from palm oil using papaya latex lipase as a catalyst. Before the synthesis carried out, palm oil is converted into methyl esters Fatty Acids (EMAL). Optimal conditions needed to form EMALTAL determined by Response Surface Method / RSM. To get the optimum conversion EMALTAL synthesis, the reaction is affected by three variables: time, papaya latex lipase levels and temperature as well as the response variable is called the optimum conversion EMALTAL synthesis. By using response surface methods (RSM), the optimal synthesis conditions obtained at a temperature of OC 39.4490, 53.2440 minutes of time and concentration of crude papaya latex $7.6600 \%$ to $28.6806 \%$ conversion of surfactant in the form of monoester. Characterization of EMALTAL 
shows the melting point of $24.5-27^{\circ} \mathrm{C}, 180^{\circ} \mathrm{C}$ smoke point and refractive index of 1.441. EMALTAL produced a monoester that serves as an emulsifier.

\section{Keywords: biosurfactant, palm oil, response surface methodology, ester maltitol fatty acid, pepaya latex lipase}

\section{PENDAHULUAN}

$\mathrm{K}$ onsumsi minyak dan lemak sering dihubungkan dengan beberapa penyakit seperti jantung koroner, obesitas, dan atherosklerosis. Pemecahan masalah ini sebenarnya mudah, tetapi sukar dalam pelaksanaannya. Pelaksanaan diet makanan tinggi minyak/lemak dan kolesterol sangat sulit terutama bagi orang yang memiliki kebiasaan makan yang kurang baik dan timbulnya gaya hidup untuk mengkonsumsi makanan siap saji. Kemajuan teknologi pangan telah dapat membantu untuk memecahkan masalah ini yaitu dengan penemuan produk pengganti minyak (oil replacer) (Murdiati, A, et al, 2003). Produk ini memiliki sifat dan fungsi seperti minyak, tetapi tidak menyumbang kalori dan menurunkan kolesterol plasma darah karena tidak terhidrolisis oleh lipase pankreas dan tidak terabsorbsi.

Penggantian konsumsi lemak dengan sumber karbohidrat dan protein banyak dilakukan. Tetapi pengembangan makanan tanpa lemak atau rendah lemak tampaknya menjadi alternatif yang banyak dipilih. Beberapa industri pangan telah mencoba dalam menawarkan variasi pilihan makanan rendah lemak tanpa mengorbankan rasa dan tekstur yang diinginkan konsumen. Pengganti lemak ideal mempunyai semua sifat atau ciri lemak disamping secara signifikan menurunkan kadar lemak dan kolesterol (Akoh, 1994).

Di pasaran telah dikenal sukrosa poliester dengan nama olestra yang terbukti tidak tercerna dan terabsorbsi oleh lipase sehingga tidak memberikan kontribusi energi dalam tubuh (Giese, 1996). Sukrosa poliester disintesa melalui transesterifikasi sukrosa dengan asam lemak dikembangkan dengan memodifikasi jenis gula maupun asam lemak yang digunakan. Umumnya digunakan asam lemak murni, asam lemak dari kedelai, minyak kacang, dan minyak kelapa sawit.
Produksi gula alkohol-poliester sudah banyak dilakukan oleh beberapa peneliti sebelumnya secara kimiawi. Tetapi, sintesis ini memiliki kelemahan yaitu adanya pewarnaan akibat suhu tinggi dan toksisitas pelarut yang dipakai. Sintesis EMALTAL dilakukan secara enzimatis untuk mencegah masalah yang dihadapai dalam proses kimiawi. Enzim yang dipakai yaitu lipase lokal getah pepaya kasar. Produksi gula alkohol-poliester diharapkan dapat menjadi alternatif dalam peningkatan nilai tambah industri minyak kelapa sawit dan meningkatkan nilai-nilai kesehatan bagi konsumen yang memilih produk tersebut.

Sumber asam lemak dalam pembuatan biosurfaktan ini adalah Ester Metil Asam Lemak (EMAL) palmitat dan stearat dari minyak kelapa sawit. EMAL dari minyak sawit digunakan dengan pertimbangan bahwa minyak sawit di Indonesia sangat melimpah. Produksi kelapa sawit tahun 2008 sebanyak $12,477,752$ ton dan 2009 sebanyak 13,872,602 ton (BPS, 2012). Produksi minyak sawit mentah (Crude Palm Oil/CPO) di Indonesia telah meningkat sangat pesat, dari 17,35 juta ton pada tahun 2006 sampai 21 juta ton pada tahun 2010 (Ditjenbun, 2013), dengan peningkatan rata-rata adalah $14,21 \%$ per tahun (Colchester et al., 2006). Menurut Hui (1996) asam lemak pada EMAL dari minyak sawit adalah terdiri dari laurat $0,1-0,3 \%$, miristat $0,9-1,5 \%$, palmitat $42,9-51,0 \%$, stearat $0,2-0,6 \%$, oleat $32,8-$ $39,8 \%$, linoleat $8,6-11,3 \%$, linolenat $0,2-$ $0,6 \%$.

EMAL mempunyai beberapa kelebihan dibandingkan asam lemak, diantaranya adalah sifat lebih mudah difraksinasi karena titik didihnya lebih rendah daripada asam lemaknya (Farris, 1979). EMAL juga lebih disukai karena stabilitasnya terhadap pembentukan wama dan degradasi oksidatif terutama jika dipanaskan, dan juga lebih stabil terhadap korosivitas. Pemakaian EMAL sebagai 
bahan dasar meningkatkan hasil sebanyak 25-30 \% lebih besar daripada menggunakan bahan dasar asam lemak (Tranggono, 1998).

Gula alkohol yang digunakan adalah maltitol. Maltitol sendiri dibentuk oleh hidrogenasi dari xilosa (Gray, 1988). Maltitol (4-0-L-D-glucopyranosyl-D-glucitol) dibentuk oleh hidrogenasi dari maltose, dihasilkan bubuk bukan kristal dan cair yang viscous. Rumus molekulnya: $\mathrm{C}_{12} \mathrm{H}_{24} \mathrm{O}_{11}$ dengan berat molekul: 344. Maltitol adalah alcohol polihidrik kristal yang dihasilkan oleh hidrogenasi dari maltose, disakarida terdiri dari dua unit glukosa yang dihubungkan dengan ikatan $L(1,4)$ (Hui, 1996).

Getah pepaya digunakan secara luas dalam industri makanan dan minuman karena memiliki aktivitas proteolitik. Getah ini juga memiliki aktivitas lipolitik dan dalam hidrolisis triasilgliserol menunjukkan aktivitas maksimal untuk asam lemak rantai pendek dan stereospesifik sn-3. Distribusi asam lemak dalam molekul lemak dapat diklasifikasikan berdasarkan stereoisomer atau atom karbon dalam molekul gliserol yakni sn-1, sn-2 dan sn-3. Penomoran stereospesifik (stereospesific numbering: sn) dari asam lemak yaitu posisi sn 1,2 dan 3 pada molekul lemak (triasilgliserol) mempengaruhi nilai gizi dan sifat fisika kimia dari lemak. Dalam reaksi esterifikasi, lipase getah pepaya menunjukkan selektivitas sn-1,3 pada asam lemak rantai medium, tetapi pertukaran acyl lebih diberatkan pada posisi sn-3 (Villeneuve et al., 1997). Penelitian lain menyatakan bahwa getah pepaya dalam reaksi esterifikasi lebih menyukai asam lemak tak jenuh cis-9 seperti asam oleat dan asam $\alpha$ linolenat. (Lee dan Foglia, 2000). Lipase memiliki sisi aktif yang dapat berinteraksi dengan substrat, sisi aktif lipase ini secara umum tersusun atas beberapa asam amino yaitu asam amino non-polar leucine, asam amino polar tidak bermuatan serine, asam amino polar bermuatan positif histidine, dan asam amino polar bermuatan negatif aspartat.

Lipase getah pepaya dipilih karena mempunyai beberapa kelebihan antara lain harga murah, mudah didapat, dan sederhana dalam pemisahannya. Selain itu pepaya merupakan tanaman yang banyak dijumpai di Indonesia. Produksi pepaya di Indonesia pada tahun 2009 mencapai 772.844 ton dan pada tahun 2010 turun menjadi 675.801 dan tahun 2011 (angka sementara) 955.078 ton (BPS, 2012).

Penelitian ini bertujuan untuk mempelajari optimasi sintesa biosurfaktan Ester Maltitol Asam Lemak (EMALTAL) dari minyak kelapa sawit dengan menggunakan lipase getah pepaya sebagai katalisator.

\section{METODE PENELITIAN}

\section{Bahan dan Alat}

Bahan yang digunakan antara lain: minyak sawit yang diperoleh dari pasar Kranggan Yogyakarta, getah pepaya, Maltitol, etanol, $\mathrm{K}_{2} \mathrm{CO}_{3}$, Butanol (Merck 99,5 $\%$ ), metanol BDH laboratory supplies 99,8 $\%$, isooktan (Merck 99,5\%), n-Hexane 99 $\%$, asam asetat glasial (Merck 99,8 \%), petroleum benzine (Merck $90 \%$ ), asam oleat (Merck $60 \%$ ), acetic anhidrade (Merck $99 \%$ ), sorbitan trioleat (span 85) sigma, sorbitan monooleat (span 80) sigma, sorbitan monopalmitat (span 40) sigma, piridin (Merck 99,3\%), diethyl eter (Merck 99,5 \%), asam sulfat (Merck 95-97\%), potassium hidroxide pellets (Merck $85 \%$ ), silika gel HF 254 (type 60) Merck.

Alat yang digunakan antara lain: reaktor pembuatan maltitol poliester berupa labu berleher tiga dengan magnetic stirrer yang dilengkapi dengan termometer dan pompa vakum. Kondisi panas reaksi dicapai dengan menggunakan pemanas yang dilengkapi thermostart. Pemurnian dan identifikasi produk menggunakan corong pisah, refraktometer Abbe, viskosimeter Brokfield, spektrofotometer. Shaker waterbath Kottermann maximal $100^{\circ} \mathrm{C} 120$ rpm, oven Memmert $200^{\circ} \mathrm{C}$, waterbath UD rekayasa Table type fryer, timbangan analitis sartorius $160 \mathrm{~g}$, UV Visible Spectrophotometer Shimadzu, alat ukur kadar air Sartorius, pembuat es Scotsman, centrifugal vacuum concentrator biotron ecospin, christ alpha 1-2 LD, vacuum controller IKA, pH meter Schott.

\section{Metode}




\section{Metode}

Kondisi optimal yang diperlukan untuk membentuk EMALTAL ditentukan dengan Response Surface Methode/RSM. Untuk mendapatkan konversi optimal sintesa EMALTAL, reaksi dipengaruhi oleh tiga variabel bebas yaitu waktu, kadar lipase getah pepaya dan suhu serta satu variabel terikat yang disebut respon yaitu konversi optimal sintesa EMALTAL. Konversi didasarkan pada selisih angka hidroksil antara menit ke-0 dan menit ke-30, 60 dan 90 , pada suhu 35,40 dan $45^{\circ} \mathrm{C}$, serta pada konsentrasi lipase getah pepaya 5, 10 dan $15 \%$.

\section{Preparasi Lipase Getah Pepaya}

Getah pepaya disadap pada buah yang masih muda menggunakan pisau stainless steel, kedalaman irisan sadap $\pm 2 \mathrm{~mm}$. Penyadapan getah pada pagi hari sekitar pukul 5 sampai 8 . Getah pepaya selanjutnya ditambah buffer fosfat dan $\mathrm{CaCl}_{2}$, kemudian dibekukan dan dikeringbekukan pada suhu $-45^{\circ} \mathrm{C}$ dengan tekanan vakum $\pm 1 \mathrm{mmbar}$. Selanjutnya getah kering digiling sampai ukuran 50 mesh, dan disimpan dalam wadah terbuat dari kaca kedap udara pada suhu dingin.

\section{Pembuatan EMAL}

Tahap selanjutnya adalah pembuatan EMAL. Bahan dasar untuk pembuatan EMAL adalah minyak kelapa sawit. Proses pembuatan EMAL dalam penelitian ini dilakukan pada suhu $80^{\circ} \mathrm{C}$ selama 1 jam, dengan katalis asam sulfat dan dalam kondisi vakum menggunakan pompa vakum. Pemvakuman bertahap untuk mencegah produk yang terbentuk tidak terikut keluar. Penambahan metanol diberikan secara berlebihan untuk menggeser kesetimbangan reaksi ke kanan sehingga produk yang terbentuk lebih banyak. Air dalam sistem reaksi bersifat menghambat reaksi esterifikasi, karena akan menggeser kesetimbangan reaksi ke kiri (menghidrolisis ester yang terbentuk). Air dalam metanol dihilangkan dengan menggunakan $\mathrm{Na}_{2} \mathrm{SO}_{4}$ anhidrat untuk mendapatkan EMAL yang lebih banyak.

Pemurnian EMAL dilakukan dengan menggunakan corong pisah. EMAL campuran akan terpisah berdasarkan bobot jenis, lapisan bawah memiliki bobot jenis lebih besar terdiri atas EMAL, sedangkan lapisan atas merupakan sisa asam lemak. EMAL yang didapat kemudian dioven pada suhu $80^{\circ} \mathrm{C}$ selama 30 menit untuk menguapkan sisa metanol yang terikut sehingga diperoleh EMAL mumi. Proses pembuatan EMAL dalam penelitian ini dapat dilihat pada Gambar 1.

\section{Penentuan Kondisi Optimum Sintesa EMALTAL Berdasarkan Angka Hidroksil}

Setelah diperoleh EMAL murni, kemudian dilakukan penentuan kondisi optimum yang meliputi waktu, suhu dan konsentrasi enzim untuk sintesa EMALTAL. Penentuan kondisi optimum sintesa EMALTAL berdasarkan angka hidroksil dapat dilihat pada Gambar 2. Angka hidroksil menunjukkan jumlah miligram $\mathrm{KOH}$ yang ekivalen dengan kandungan hidroksil dalam $1 \mathrm{~g}$ sampel. Maltitol memiliki 5 gugus hidroksill dan bila maltitol teresterkan dengan EMAL, maka kandungan gugus hidroksillnya akan menurun dan angka hidroksillnya juga semakin kecil. Oleh karena itu, angka hidroksill ini dapat digunakan sebagai parameter keberhasilan proses esterifikasi.

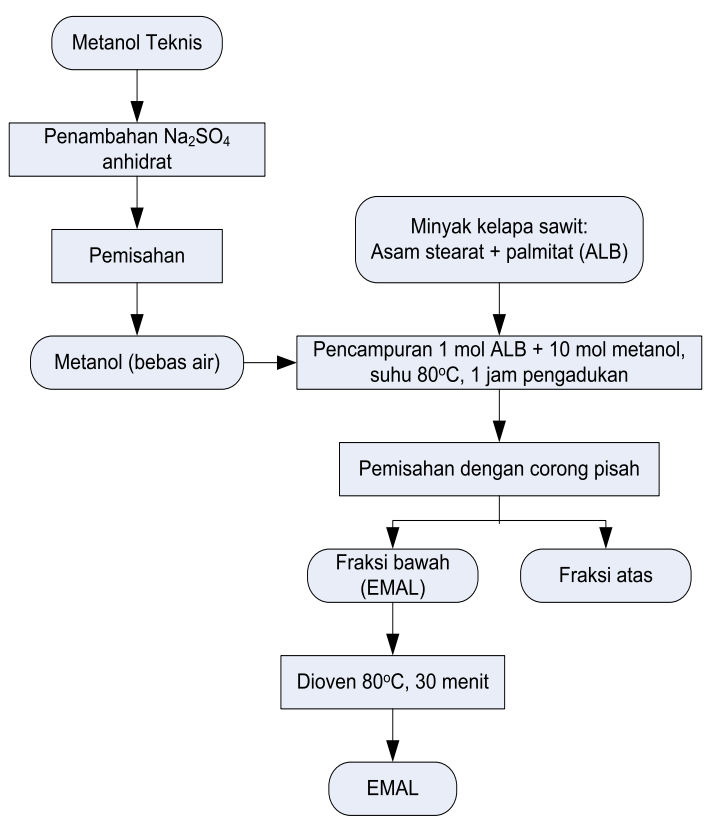

Gambar 1. Pembuatan EMAL 


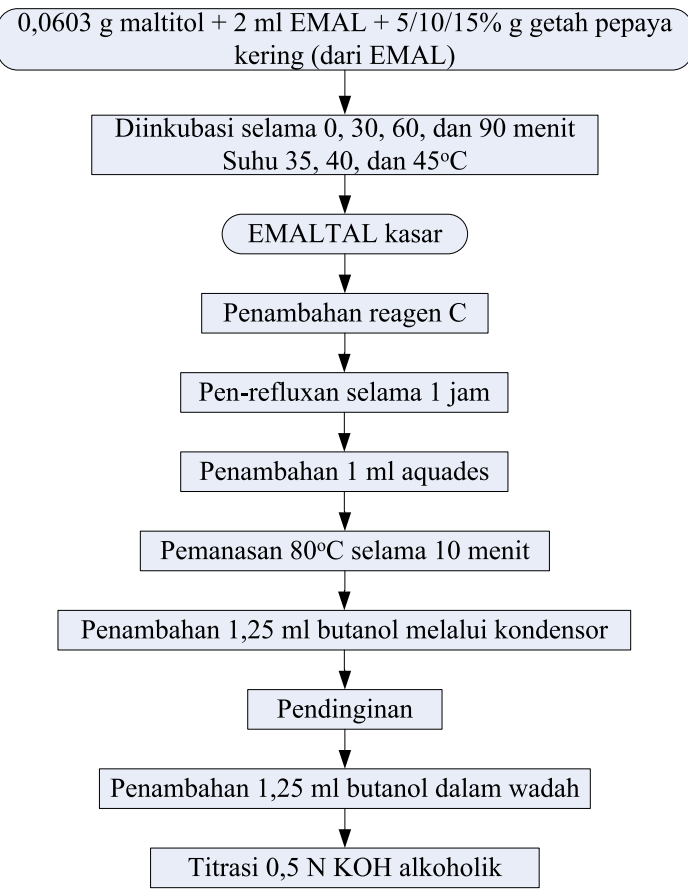

Gambar 2. Optimasi sintesa EMALTAL berdasarkan angka hidroksil

\section{Pembuatan EMALTAL}

Penentuan titik optimum sintesis EMALTAL diperoleh berdasarkan hasil orientasi sintesis EMALTAL dengan variasi suhu (pada waktu dan konsentrasi enzim tetap), variasi waktu (pada suhu dan konsentrasi tetap) dan variasi konsentrasi enzim (pada suhu dan waktu tetap).

Kondisi optimum sintesa EMALTAL yang meliputi waktu, suhu dan konsentrasi enzim ditentukan dengan menggunakan metode Response Surface Method (RSM). Berdasarkan kondisi optimum tersebut, maka tahap selanjutnya adalah proses pembuatan EMALTAL seperti terlihat pada Gambar 3.

\section{Metode Analisis}

Penentuan angka hidroksil dilakukan sebagai dasar perhitungan konversi karena menggambarkan efektifitas pengikatan hidroksil maltitol terhadap asam lemak (AOAC, 1995). Analisis kandungan asam lemak yang terdapat di dalam maltitol polyester (EMALTAL) dilakukan dengan gas chromatografy. Analisis lain adalah penentuan titik leleh (AOAC, 1995), titik asap (AOAC, 1995) dan indeks refraksi (AOAC, 1995).

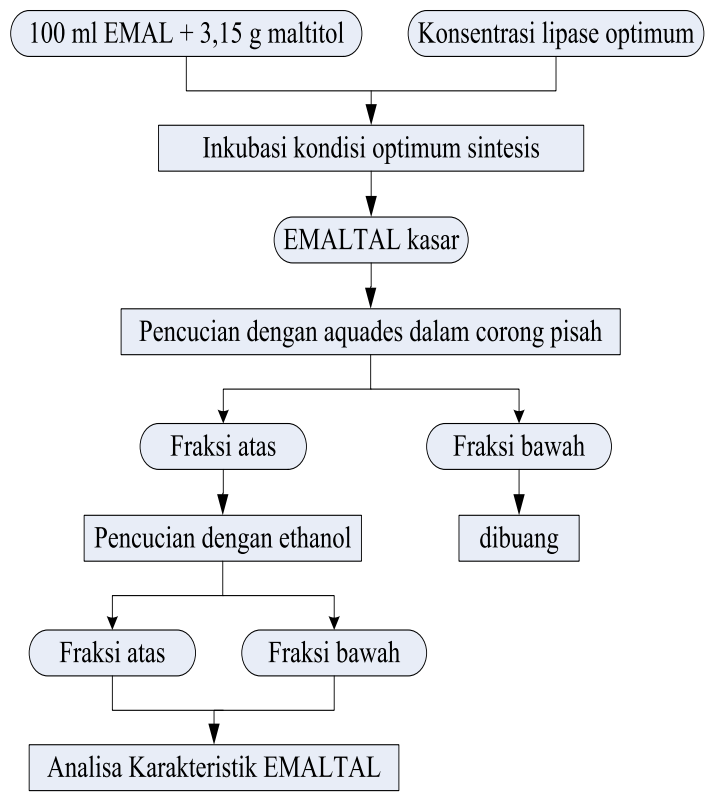

Gambar 3. Pembuatan EMALTAL Enzimatis

\section{HASIL DAN PEMBAHASAN}

\section{Angka Hidroksil}

Angka hidroksil menunjukkan jumlah miligram $\mathrm{KOH}$ yang ekuivalen dengan kandungan hidroksil dalam 1 gram sampel. Maltitol mempunyai 5 gugus hidroksil. Semakin kecil angka hidroksil gula alkohol poliester menunjukkan bahwa proses esterifikasi semakin baik (derajat esterifikasi yang diperoleh tinggi). Berdasarkan hasil tersebut, getah pepaya memiliki aktivitas sebagai enzim lipase dalam mengkatalis EMAL dan maltitol menjadi EMALTAL.

\section{Kondisi Optimum Sintesa EMALTAL}

Kondisi-kondisi yang diperkirakan optimum untuk sintesa EMALTAL diketahui dengan metode response surface methodology. Berdasarkan RSM maka dapat ditentukan secara tepat kondisi sintesa EMALTAL optimum. Kondisi optimum sintesa ditunjukkan pada Tabel 1.

Data hasil perkiraan titik optimal sintesa EMALTAL pada Tabel 1 dibuat dalam bentuk grafik kontour masing-masing untuk waktu 30, 60, dan 90 menit, konsentrasi enzim 5, 10, dan $15 \%$ dan suhu 35,40 dan $45^{\circ} \mathrm{C}$. Grafik kontour menunjukkan daerah-daerah optimal yang akan digunakan untuk pembuatan EMALTAL seperti pada Gambar 4. 
Tabel 1. Perkiraan Titik Optimal EMALTAL

\begin{tabular}{|c|c|c|c|c|c|c|}
\hline \multicolumn{3}{|c|}{ Tak kode } & \multicolumn{3}{|c|}{ Kode } & \multirow{2}{*}{$\begin{array}{c}\text { Konversi } \\
(\%)\end{array}$} \\
\hline Suhu(oC) & Waktu (menit) & Enzim (\%) & Suhu & Waktu & Enzim & \\
\hline 40 & 90 & $10 \%$ & 0 & 1 & 0 & 0.00 \\
\hline 35 & 90 & $10 \%$ & -1 & 1 & 0 & 0.00 \\
\hline 35 & 60 & $10 \%$ & -1 & 0 & 0 & 0.00 \\
\hline 45 & 30 & $10 \%$ & 1 & -1 & 0 & 0.00 \\
\hline 45 & 90 & $10 \%$ & 1 & 1 & 0 & 0.00 \\
\hline 45 & 60 & $10 \%$ & 1 & 0 & 0 & 1.06 \\
\hline 35 & 60 & $15 \%$ & -1 & 0 & 1 & 1.81 \\
\hline 45 & 90 & $5 \%$ & 1 & 1 & -1 & 6.25 \\
\hline 40 & 90 & $15 \%$ & 0 & 1 & 1 & 6.83 \\
\hline 40 & 60 & $5 \%$ & 0 & 0 & -1 & 7.94 \\
\hline 45 & 90 & $15 \%$ & 1 & 1 & 1 & 8.82 \\
\hline 40 & 60 & $10 \%$ & 0 & 0 & 0 & 9.00 \\
\hline 45 & 60 & $5 \%$ & 1 & 0 & -1 & 9.34 \\
\hline 45 & 30 & $15 \%$ & 1 & -1 & 1 & 9.80 \\
\hline 45 & 30 & $5 \%$ & 1 & -1 & -1 & 9.87 \\
\hline 35 & 90 & $5 \%$ & -1 & 1 & -1 & 10.80 \\
\hline 40 & 90 & $5 \%$ & 0 & 1 & -1 & 10.95 \\
\hline 35 & 60 & $5 \%$ & -1 & 0 & -1 & 11.96 \\
\hline 35 & 30 & $5 \%$ & -1 & -1 & -1 & 12.98 \\
\hline 35 & 90 & $15 \%$ & -1 & 1 & 1 & 15.38 \\
\hline 40 & 30 & $5 \%$ & 0 & -1 & -1 & 16.26 \\
\hline 45 & 60 & $15 \%$ & 1 & 0 & 1 & 19.61 \\
\hline 35 & 30 & $10 \%$ & -1 & -1 & 0 & 20.18 \\
\hline 40 & 60 & $15 \%$ & 0 & 0 & 1 & 20.23 \\
\hline 35 & 30 & $15 \%$ & -1 & -1 & 1 & 26.92 \\
\hline 40 & 30 & $15 \%$ & 0 & -1 & 1 & 32.64 \\
\hline 40 & 30 & $10 \%$ & 0 & -1 & 0 & 40.94 \\
\hline
\end{tabular}

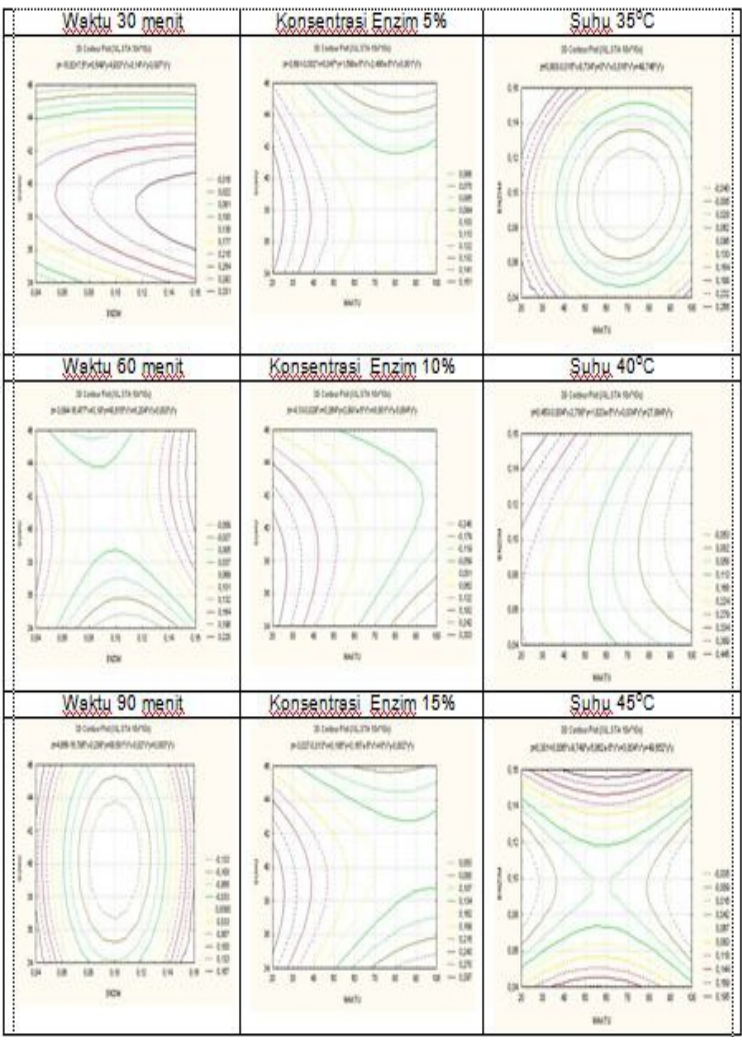

Gambar 4. Grafik Kontour Perkiraan Kondisi Optimal

Berdasarkan Gambar 4, kondisi optimal sintesis EMALTAL diperoleh pada waktu 90 menit, konsentrasi enzim 10\% dan suhu 350C. Pada kondisi tersebut, grafik menunjukkan bentuk kontour optimal. Hasil perhitungan RSM dapat dilihat pada Tabel 2 dan Tabel 3.

Tabel 2. Hasil Perhitungan RSM

Model: $k v=a 0+a 1^{*} x 1+a 2^{*} x 2+a 3^{*} x 3+a 4^{*} x 1^{\wedge} 2+a 5^{*} x 2^{\wedge} 2+a 6^{*} x 3^{\wedge} 2+a 7^{*} x 1^{*} x 2+a 8^{*} x 1^{*} x 3+a 9^{*} x 2^{*} x 3$

Dep. var: KV Loss: (OBS-PRED) ${ }^{* *} 2$

Final loss: .058702986 R=.83050 Variance explained: $68.974 \%$

\begin{tabular}{|l|r|l|l|l|l|l|l|l|l|l|}
\hline & A0 & A1 & A2 & A3 & A4 & A5 & A6 & A7 & A8 & A9 \\
\hline Estimate & 0.269563 & 0.083119 & 0.02306 & -0.068972 & -0.04936 & -0.06304 & -0.11523 & 0.075542 & 0.164511 & 0.092153 \\
\hline Std.Err. & 0.056445 & 0.078536 & 0.045759 & 0.072587 & 0.081847 & 0.074284 & 0.087733 & 0.065019 & 0.116277 & 0.072771 \\
\hline $\mathrm{t}(5)$ & 4.775687 & 1.058351 & 0.503954 & -0.950202 & -0.60312 & -0.84861 & -1.31347 & 1.161845 & 1.414828 & 1.266351 \\
\hline p-level & 0.00499 & 0.338323 & 0.635709 & 0.385644 & 0.572741 & 0.434833 & 0.246065 & 0.29774 & 0.216267 & 0.261177 \\
\hline
\end{tabular}


Tabel 3. Polinomial Tingkat 2

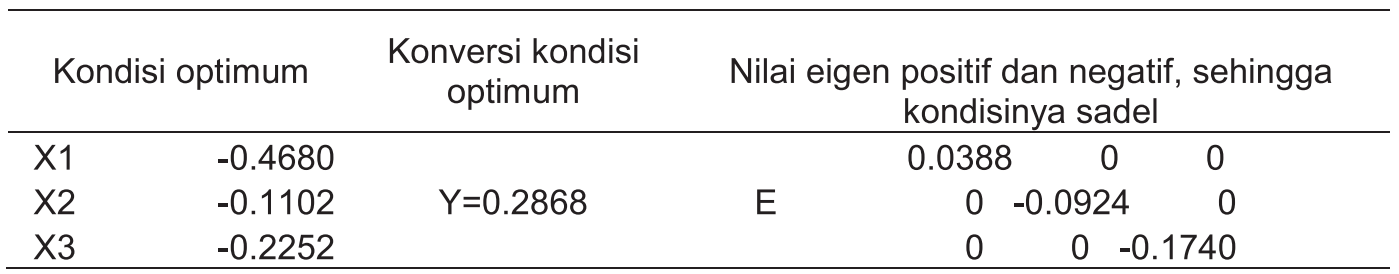

Analisis kanonis untuk persamaan polinomial tingkat dua adalah:

$Y=0,2868+0.0388 X_{1}^{2}-0,0924 X_{2}^{2}-0.1740 X_{3}^{2}$

Waktu optimal $\quad: 53,24$ menit, Konsentrasi optimal $\quad: 7,66 \%$

Suhu optimal $\quad: 39,45^{\circ} \mathrm{C}, \quad$ Konversi (EMALTAL) $\quad: 28,68 \%$

Dari hasil perhitungan RSM, secara teori suhu, waktu, dan konsentrasi enzim optimal sebesar $39,45^{\circ} \mathrm{C}, 53,24$ menit, 7 , $66 \%$, dan ester yang terbentuk sebanyak $28,68 \%$ dari seluruh bahan. Konversi ini menunjukkan bahwa surfaktan yang terbentuk merupakan monoester karena lipase getah pepaya spesifik pada C primer, tidak terbentuknya diester mungkin disebabkan waktu inkubasi kurang lama dan suhu belum benar-benar mencapai kondisi optimal untuk aktivitas esterifikasi pada atom $\mathrm{C} 1$ dan 3 sekaligus.

\section{Titik Leleh}

Titik leleh produk maltitol ester 24,5 27 , lebih tinggi daripada titik leleh minyak sawit $\left(20-24^{\circ} \mathrm{C}\right)$. Titik leleh dipengaruhi oleh tingkat ketidakjenuhan dan panjang rantai asam lemak penyusunnya. Asam lemak dengan ikatan antar molekul yang semakin kuat mengakibatkan makin banyak panas yang diperlukan untuk pencairan, sehingga energi panas yang diperlukan untuk mencairkan kristal makin banyak dan titik leleh lebih tinggi. Hal ini ditentukan oleh panjang rantai $\mathrm{C}$, jumlah ikatan rangkap, bentuk cis atau trans pada asam lemak tidak jenuh. Makin panjang rantai $\mathrm{C}$ titik leleh akan semakin tinggi. Titik leleh turun dengan bertambahnya jumlah ikatan rangkap karena ikatan antar molekul asam lemak tidak jenuh kurang kuat sebab rantai pada ikatan rangkap (cis) tidak lurus. Makin banyak ikatan rangkap, ikatan makin lemah sehingga titik cair lebih rendah (Winarno,2008).

Asam lemak jenuh mempunyai titik leleh yang lebih tinggi dari asam lemak tidak jenuh. Bentuk trans pada asam lemak mempunyai titik leleh lebih tinggi daripada cis (Winarno,2008). Hal ini menunjukkan bahwa EMALTAL memiliki asam lemak rantai panjang. Dimana asam lemak yang digunakan adalah asam Palmitat-Stearat $\left(\mathrm{C}_{16: 0}\right.$ dan $\left.\mathrm{C}_{18: 0}\right)$.

\section{Titik Asap (smoke point)}

Titik asap (smoke point) berguna untuk mengetahui produk tersebut dapat digunakan untuk menggoreng atau tidak. EMALTAL memiliki titik asap $180^{\circ} \mathrm{C}$. Menurut Lewis (1987), titik asap yang biasa digunakan untuk menggoreng sekitar $>160^{\circ}$ $C$, sehingga EMALTAL dapat digunakan untuk menggoreng. Menurut Ketaren (1986), titik asap tergantung kadar asam lemak bebas, semakin banyak asam lemak bebas maka semakin rendah titik asap.

\section{Indeks Refraksi}

Indeks refraksi dipengaruhi oleh derajat ketidakjenuhan asam lemak, panjang rantai asam lemak, polimerisasi thermal. Perubahan indeks refraksi disebabkan karena pemanasan yang menyebabkan polimerisasi thermal sehingga rantai $\mathrm{C}$ semakin panjang. Makin tinggi derajat ketidakjenuhan, suhu semakin tinggi.

Indeks refraksi minyak kelapa sawit 1,439 (Sarni, 2002). Indeks refraksi sering digunakan untuk mengetahui kemurnian minyak. Indeks refraksi EMALTAL 1,441 $\left(26^{\circ} \mathrm{C}\right)$. Indeks bias karbohidrat poliester pada umumnya lebih besar daripada indeks refraksi minyak karena diester memiliki molekul yang lebih besar, yang disebabkan 
oleh banyak asam lemak yang terikat pada inti karbohidrat.

\section{KESIMPULAN}

Dari hasil perhitungan RSM, menunjukkan suhu, waktu, dan konsentrasi enzim optimal sebesar $39,45^{\circ} \mathrm{C}, 53,24$ menit, $7,66 \%$, dan ester yang terbentuk sebanyak $28,68 \%$ (monoester). EMALTAL memiliki titik leleh $24,5-27^{\circ} \mathrm{C}$, titik asap $180^{\circ} \mathrm{C}$ dan indeks refraksi 1,441. EMALTAL mempunyai derajat esterifikasi kurang dari empat sehingga dapat berfungsi sebagai emulsifier. Untuk memperbesar produk esterifikasi yaitu dengan mengambil metanol yang terbentuk selama esterifikasi berlangsung dan menggunakan sistem kontinyu. Penggunaan sistem kontinyu lebih efektif dan efisien untuk konfirmasi akhir produk, meskipun tidak menutup kemungkinan untuk dilanjutkan pada sintesa EMALTAL berikutnya.

\section{DAFTAR PUSTAKA}

Akoh, CC. 1994. Synthesis of carbohydrate fatty acid polyester, dalam Akoh, C.C dan Swanson B.G (ed), Carbohydrate polyester as fat substitutes pp 19-35. Marcell Dekker Inc, New York.

AOAC, 1995. Official Methods of Analysis of the Association of Official Analysis Chemists. Sidney W. (ed.). The AOAC Inc., Virginia, USA.

Biro Pusat Statistik. 2012, Statistika Indonesia, Jakarta: Biro Pusat Statistik, (diakses 07 Juni 2012).

Colchester, M, Surambo A, Herbert, P, Jiwan. N, Andiko, Sirait M, Firdaus A.W. 2006. Tanah yang Dijanjikan : Minyak Sawit dan Pembebasan Tanah di Indonesia Implikasi terhadap Masyarakat Lokal dan Masyarakat Adat. Bogor : Forest Peoples Programme \& Perkumpulan Sawit Watch.

Farris, R.D., 1979. Methyl Esters in The Fatty Acid Industry. JAOCS (56) : 770773 A.
Giese, J., 1996. "Olestra : Properties, Regulatory Concerns and Applications", Food Technology 50 : $130-131$.

Gray, J., 1988. Starches and Sugars. A Comparison of their Metabolism in Man. Springer-Verlag London Ltd, Wimbledon, London.

Hui, Y.H. 1996. Bailey's Industrial Oil and Fat Products. Volume 2. Edible Oil and Fat Product: Oils and Oil Seeds. Pp 241-270. New York: John Wiley and Sons, Inc.

Ketaren, S.1986. Pengantar Teknologi Minyak dan Lemak. Jakarta: UI Press.

Lee, K.T. dan Foglia, T.A. 2000. Synthesis, Purification, and Characterization of Structured Lipids Produced from Chicken Fat. Paper no.J9532 in JAOCS: 1027-1034

Lewis, M.J.1987. Physical Properties of Food and Food Processing System. Chichester, Inggris: Ellis Horwood Ltd.

Murdiati, A, Suhardi dan Marsono, Y, 2003. Studi Kinetika Kerusakan Minyak Goreng Rendah Kalori, Maltitol Poliester Selama Penggorengan. Lembaga Penelitian UGM, Yogyakarta. Karya IImiah Hasil Penelitian.

Sarni, 2002. Optimasi Suhu Bleaching Pembuatan Sorbitol Poliester dari Minyak Sawit (Elais guineensis). Skripsi S1 Fakultas Teknologi Pertanian UGM, Yogyakarta.

Tranggono, Suhardi, R. Armunanto, dan Supranto, 1998b, "Tinjauan Kinetik Kondisi Optimum Reaki Pembentukan Ester Metil Asam Lemak (EMAL)", Prosiding Seminar Nasional Teknologi Pangan dan Gizi. pp 166-171.

Villeneuve,P et al. 1997. "Specificity of C. pepaya Latex in Lipase catlyzed Interesterification Reactions", Biotechnol. Tech. 11: 91-94.

Winarno, F.G., 2008. Kimia Pangan dan Gizi. Jakarta: PT Gramedia.

www.ditjenbun,deptan.go.id. Produksi CPO Indonesia. (Akses 11 Januari 2013). 